\title{
Vaginal Fistula
}

National Cancer Institute

\section{Source}

National Cancer Institute. Vaginal Fistula. NCI Thesaurus. Code C79847.

An abnormal communication between the vagina and another org an or cavity. 